\title{
Kombinasi Ciri Bentuk dan Ciri Tekstur Untuk Identifikasi Penyakit Pada Tanaman Padi
}

\author{
Noor Abdul Haris*1, Hari Asgar ${ }^{2}$, Janeman Sumah, Kusrini ${ }^{4}$ \\ 1,2,3,4 Jurusan S2 Teknik Informatika; Universitas AMIKOM Yogyakarta, (0274) 884201 \\ e-mail: *11 noor.haris@students.amikom.ac.id, ${ }^{2}$ hari.asgar@students.amikom.ac.id, \\ 3janeman.28@students.amikom.ac.id, ${ }^{4}$ kusrini@amikom.ac.id
}

\begin{abstract}
Abstrak
Mayoritas petani di Jawa Tengah, khususnya Sragen, menanam padi. Namun banyak kendala yang mereka hadapi, terutama masalah penyakit yang menyerang tanaman padi. 5 jenis penyakit padi yang sering dijumpai, yaitu bercak daun, blas, hawar daun, pelepah flare, dan tungro. Kurangnya pemahaman menyebabkan kesalahan dalam penanganan, dapat menyebabkan kerugian. Tujuan penelitian ini adalah untuk meningkatkan akurasi dalam mengidentifikasi penyakit tanaman padi yang terkena penyaki. Mengidentifikasi jenis penyakit pada tanaman padi dengan menggabungkan karakteristik bentuk dan karakteristik tekstur menjadi penting untuk meningkatkan hasil akurasi. Metode yang digunakan mempengaruhi keakuratan masing-masing pola dalam citra tanaman padi. Data yang digunakan adalah 70 data latih dan 30 data uji dengan ukuran 256 x 256 piksel. Kombinasi karakteristik bentuk dan tekstur digunakan untuk mengoptimalkan akurasi. Untuk mendapatkan karakteristik proses segmentasi menggunakan Otsu dan Morfologi. Hasilnya diproses untuk mendapatkan karakteristik bentuk menggunakan luas dan perimeter, dan karakteristik entropi, energi, homogenitas, korelasi, dan tekstur kontras, masing-masing dari 4 sudut GLCM, sehingga fitur yang digunakan adalah 22 fitur. Sistem ini menggunakan metode backpropagation untuk mengklasifikasikan jenis penyakit. Hasil yang diperoleh dari 70 data pelatihan adalah akurasi $100 \%$ dan 30 data uji dengan tingkat akurasi $93 \%$.
\end{abstract}

Kata kunci- Penyakit Padi, Ciri Bentuk, Ciri Tekstur, GLCM

\begin{abstract}
The majority of farmers in Central Java, especially Sragen, grow rice. But many obstacles they face, especially the problem of diseases that attack rice plants. 5 types of rice diseases that are often found, namely leaf spot, blast, leaf blight, fronds, and tungro. Lack of understanding causes errors in handling, can cause harm. The purpose of this study is to improve accuracy in identifying diseases of rice plants affected by the disease. Identification of types of diseases in rice plants by combining the characteristics of shape and texture characteristics is important to improve the accuracy of the results. The method used influences the accuracy of each pattern in the image of rice plants. The data used are 70 training data and 30 test data with a size of $256 \times 256$ pixels. A combination of shape and texture characteristics is used to optimize accuracy. To get the characteristics of the segmentation process using Otsu and Morphology. The results are processed to obtain the shape characteristics using area and perimeter, and the characteristics of entropy, energy, homogeneity, correlation, and contrast texture, each of the 4 angles of GLCM, so that the features used are 22 features. This system uses a backpropagation method to classify types of diseases. The results obtained from 70 training data are 100\% accuracy and 30 test data with an accuracy level of $93 \%$.
\end{abstract}


Keywords - Rice Disease, Shape Characteristics, Texture Characteristics, GLCM

\section{PENDAHULUAN}

Padi merupakan salah satu tanaman pokok bagi sebagian besar masyarakat di Indonesia. Tanaman padi (Oryza sativa) merupakan makanan pokok yang memiliki peranan penting dalam memenuhi kebutuhan pangan di Indonesia [1]. Pengenalan jenis penyakit pada tanaman padi yang menyerang sangat penting untuk menunjang keberhasilan petani dalam usaha pengendalian. Pengetahuan petani terbatas pada penyuluhan dan pengetahuan yang mereka miliki [2].

Untuk itu menjadi penting adanya sistem yang dapat digunakan untuk membantu petani mengidentifikasi penyakit pada tanaman padi. Tujuannya dapat mempermudah petani dalam mengetahui jenis penyakit yang ada pada tanaman padi sehingga memudahkan petani dalam mengambil tindakan atau antisipasi sehingga tidak mengalami kerugian. Penyakit pada tanaman bisa dilihat dari perubahan daun, akar, batang dan lain-lain seperti yang dilakukan oleh [3]-[11] tak terkecuali pada tanaman padi [12], [13].

Penelitian yang dilakukan sebelumnya menggunakan image tanaman yang sehat dan yang sakit baik dari ciri warna [6] [9] [14] [15], ciri bentuk [16] dan ciri tekstur[12], [13] [15]. Agar hasil citra dapat maksimal waktu dilakukan pemrosesan maka dilakukan ROI (Region of Interest) pada bagian yang diasumsikan terkena penyakit.

Perbaikan citra perlu dilakukan untuk meningkatkan hasil citra, awal perbaikan dilakukan proses konversi warna [16] [3] pada penelitian ini dilakukan konversi warna dari RGB ke grayscale. Selanjutnya diproses menggunakan contrast stretching, dengan tujuan untuk mendapatkan citra baru dengan kontras yang lebih baik dari pada kontras dari citra asal.

Tahap selanjutnya dilakukan segmentasi [3] [12] [16] untuk mendapatkan ciri yang akan digunakan. Metode segmentasi yang digunakan dalam penelitian ini adalah metode otsu dan morfologi. Otsu merupakan global thresholding, digunakan untuk melakukan analisis diskriminan. Analisis Diskriminan berfungsi agar variabel dapat membagi objek latar depan (foreground) dan latar belakang (background) secara otomatis. Metode morfologi opening digunakan untuk menghilangkan objek-objek kecil dan membuat tepi citra lebih smooth (untuk citra berukuran besar), sedangkan closing bertujuan untuk mengisi lubang kecil pada objek, menggabungkan objek yang berdekatan.

Proses ekstraksi ciri [12] untuk mendapatkan ciri yang digunakan untuk membedakan class satu dengan yang lain. Ekstraksi ciri bentuk dilakukan dengan perhitungan area dan perimeter. Sedangkan untuk ekstraksi ciri tekstur menggunakan GLCM empat sudut yaitu 00, 450, 900, dan 1350. Dari ekstraksi ciri tekstur masing-masing sudut digunakan lima ciri yaitu ciri energy, kontras, homogeinity, entropy dan korelasi. Sehingga total ciri tekstur ada 20 ciri.

Hasil ciri diklasifikasi kedalam 5 class, yaitu Bercak, Blas, HDaun, HPelepah dan Tungro. Klasifikasi dilakukan menggunakan jaringan syaraf tiruan backpropagation. Dalam proses klasifikasi menyesuaikan tiap bobot dan bias berdasarkan nilai error yang didapat pada saat forward pass. Pada proses perhitungannya menerapkan metode gradient descent untuk meminimalkan error kuadrat total dari keluaran yang dihitung oleh jaringan.

Dari penelitian yang telah dilakukan sebelumnya masing-masing menggunakan ciri bentuk atau ciri tekstur sehingga hasil yang diperoleh kurang optimal, untuk itu menjadi penting pada penelitian ini menggabungkan antara ciri bentuk dan ciri tekstur, sehingga dapat meningkatkan hasil akurasi identifikasi citra. 


\section{METODE PENELITIAN}

Metode yang digunakan dalam penelitian ini diawali dengan akuisisi data, perbaikan citra, segmentasi dan ekstraksi ciri dengan menggabungkan antara ciri bentuk dan ciri tekstur, hasil ciri di klasifikasi menggunakan metode backpropagation yang terbagi menjadi 5 class yaitu class Bercak, Blas, HDaun, HPelepah dan Tungro. Data yang digunakan sebanyak 100 data citra tanaman padi, yang terbagi menjadi 70 data latih dan 30 data uji. Metode yang digunakan dalam penelitian ditunjukkan pada diagram penelitian yang ditunjukkan pada Gambar 1.

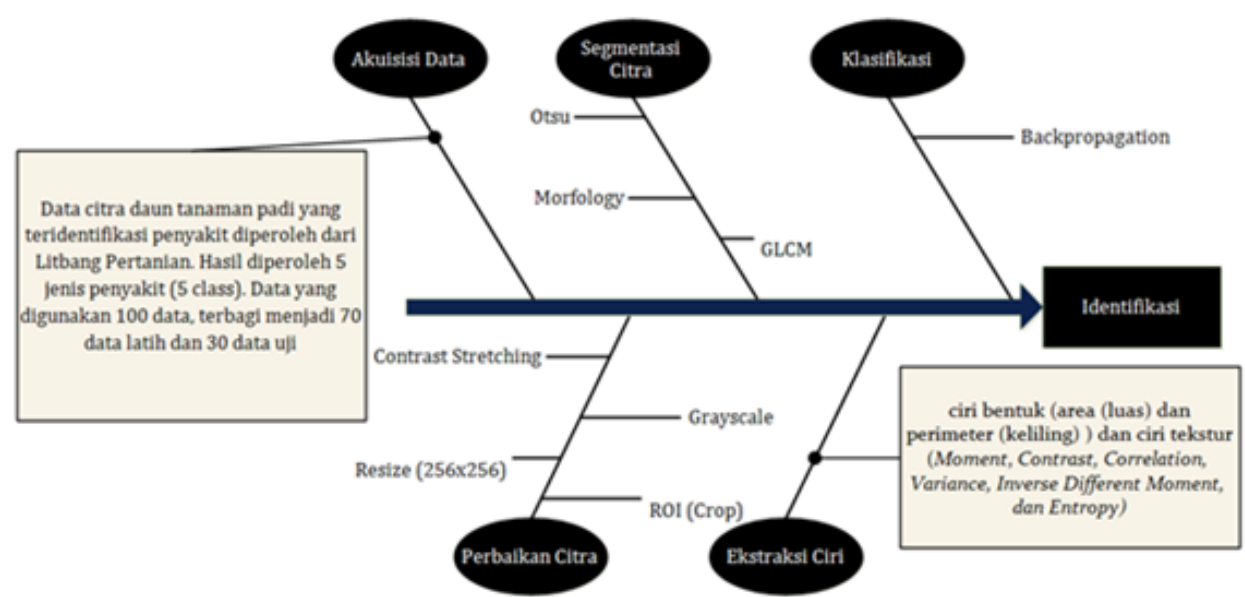

Gambar 1. Diagram Proses Penelitian

\subsection{Akuisisi Data}

Akuisi data adalah tahap awal untuk mendapatkan citra digital. Tujuan akuisisi data adalah untuk menentukan data yang diperlukan dan memilih metode perekaman citra digital. Tahap ini dimulai dari objek yang akan diambil gambarnya, persiapan alat-alat sampai pada penyimpanan data citra yang akan digunakan dengan pendampingan dari ahli di bidang pertanian padi. Data yang digunakan sebanyak 100 data citra padi, yang terbagi menjadi 70 data latih dan 30 data uji. Proses akuisisi data ditunjukkan pada Gambar 2.

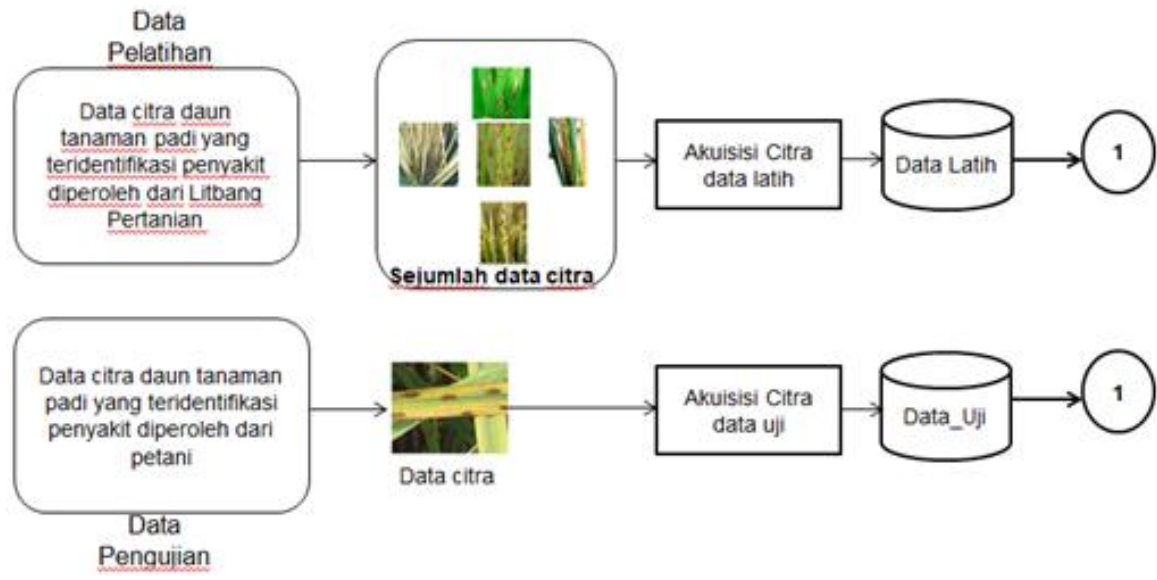

Gambar 2. Proses Akuisisi Data 


\section{1.1 Perbaikan Citra}

Proses perbaikan citra, setelah mendapatkan citra daun yang teridentifikasi penyakit, citra daun memiliki beberapa objek yang terdiri dari citra daun yang terkena penyakit dan bagian dari tanaman padi. Untuk mengatasi masalah tersebut dilakukan proses perbaikan citra. Metode perbaikan citra yang digunakan pada penelitian ini adalah ROI (Region of Interest), resize, grayscale dan contrast stretching. Gambar 3 menunjukkan proses perbaikan citra.

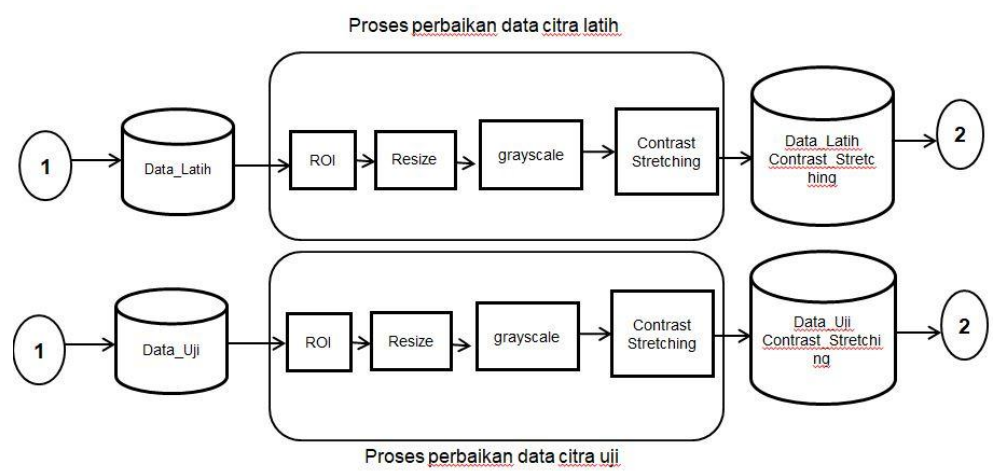

Gambar 3. Proses Perbaikan Citra

Rumus perbaikan citra dari RGB ke grayscale ditunjukkan pada persamaan (1)-(4) sebagai berikut: [17]

$$
\text { Grayscale }=0.299 \mathrm{R}+0.587 \mathrm{G}+0.114 \mathrm{~B}(1)
$$

Dilanjutkan dengan rumus contrast stretching,

untuk $0 \leq \mathrm{r} \leq \mathrm{r} \_1$,

untuk $\mathrm{r}_{-} 1 \leq \mathrm{r} \leq \mathrm{r} \_2$,

$$
\text { maka } \mathrm{s}=\mathrm{r} \mathrm{s}_{-} \_1 / \mathrm{r}_{-} 1(2)
$$

untuk r_ $2 \leq r \leq 255$

$$
\text { maka s= s_1+((r-r_1 )*(s_2-s_1) }) /\left(\left(r \_2-r \_1\right)\right)(3)
$$

$$
\text { maka s=s_2+((r-r_2 } \left.) *\left(255-\mathrm{s} \_2\right)\right) /\left(\left(255-\mathrm{r} \_2\right)\right)(4)
$$

\subsection{Segmentasi Citra}

Proses segmentasi citra, segmentasi merupakan teknik untuk memisahkan atau membagi antara foreground dan background pada suatu citra. Pada penelitian ini untuk fitur bentuk menggunakan teknik Otsu, dan morfology hasil disimpan dalam folder Foto_Padi dan untuk fitur tekstur menggunakan metode GLCM. Gambar 4 menunjukkan proses segmentasi. 


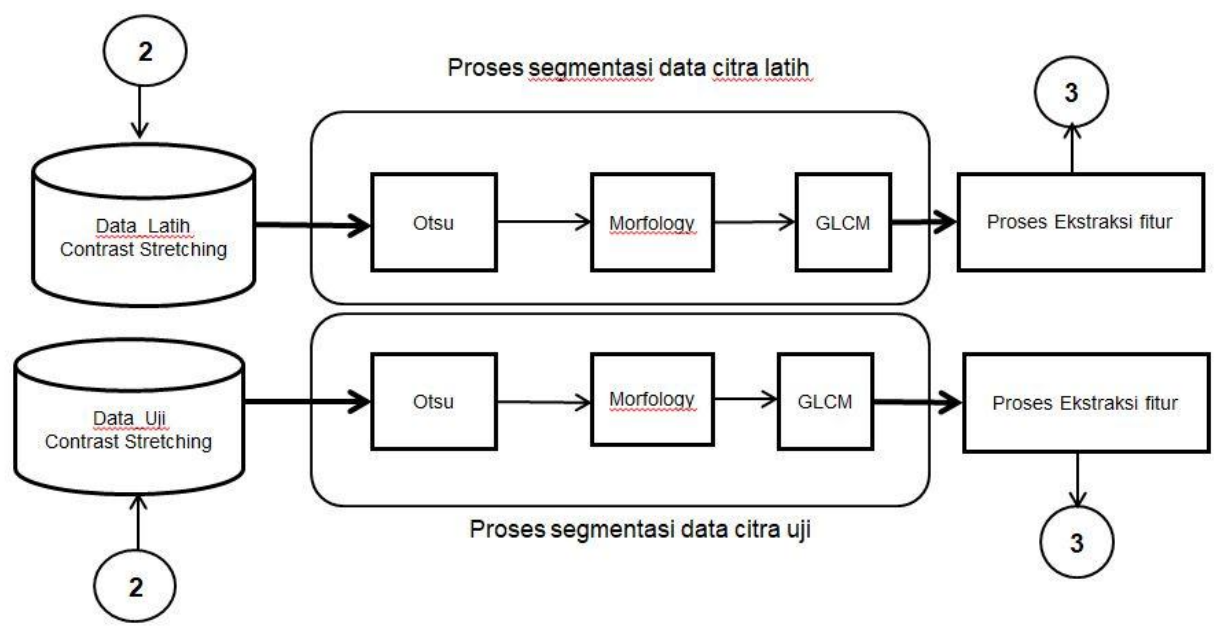

Gambar 4. Proses Segmentasi Citra

Algoritma Otsu:

Hitunglah histogram ternormalisasi dari citra. Simbolkan histogram tersebut sebagai $\mathrm{p}_{\mathrm{i}}$, $\mathrm{i}=0,1,2 \ldots . \mathrm{L}-1$ ditunjukkan pada persamaan (5)-(9).[17]

$$
p_{i}=\frac{n_{i}}{M N}
$$

Dengan $n_{i}$ adalah jumlah piksel pada tiap intensitas dan $M N$ adalah jumlah semua $n_{i}$ mulai dari $\mathrm{n}_{0}$ sampai $\mathrm{n}_{\mathrm{L}-1}$

Hitunglah jumlah kumulatif (cumulative sum) dari $\mathrm{P}_{1}(\mathrm{k})$, untuk $\mathrm{k}=0,1,2 \ldots \mathrm{L}-1$ dengan menggunakan rumus

$$
P_{1}(k)=\sum_{i=0}^{k} p_{i}
$$

Hitunglah rerata kumulatif (cumulatif mean), $\mathrm{m}(\mathrm{k})$ untuk $\mathrm{k}=0,1,2, \ldots \mathrm{L}-1$ dengan menggunakan rumus,

$$
m(k)=\sum_{i=0}^{k} i p_{i}
$$

Rumus untuk menghitung area dan perimeter,

$$
\begin{gathered}
\text { Area }=\sum_{x} \sum_{y} f(x, y) \\
\text { Perimeter }=\sum_{x} \sum_{y} f(x, y), x, y \in \text { Boundary region }
\end{gathered}
$$

\subsection{Ekstraksi Ciri}

Ekstraksi ciri tekstur dengan GLCM 4 sudut, digunakan matriks kookurensi, matriks yang merepresentasikan hubungan ketetanggaan antar pixel pada citra dari berbagai arah orientasi dan jarak spasial,

a. Energi (Angular Second Moment)

Nilai energi tinggi apabila terdapat kemiripan nilai pixel antara satu dengan yang lain, dan akan bernilai kecil jika tidak ada kemiripan menandakan nilai dari GLCM normalisasi adalah heterogen ditunjukkan pada persamaan (10). 


$$
\sum_{i=1}^{K} \sum_{j=1}^{K} p_{i^{2} j}
$$

b. Entropi (Entropy)

Mengukur kompleksitas suatu citra. Saat citra tidak seragam maka nilai Entropy akan tinggi. Energi berbanding terbalik dengan entropy dirunjukkan pada persamaan (11)

\section{c. Kontras (Contrast)}

$$
\sum_{i=1}^{K} \sum_{j=1}^{K} p_{i j} \log _{2} p_{i j}
$$

Perbedaan moment GLCM diukur berdasarkan frekuensi spatial dari suatu citra. frekuensi spatial adalah perbedaan tinggi dan rendahnya suatu pixel. Kontras akan bernilai 0 jika pixel ketetanggaan memiliki nilai sama ditunjukkan pada persamaan (12).

$$
\sum_{i=1}^{K} \sum_{j=1}^{K}(i-j)^{2} p_{i j}
$$

\section{d. Homogeniti (Homogeneity)}

Homogeniti atau Inverse Difference Moment digunakan untuk mengukur homogenitas citra ditunjukkan pada persamaan (13).

$$
\sum_{i=1}^{K} \sum_{j=1}^{K} \frac{p_{i j}}{1+|i-j|}
$$

\section{e. Korelasi (Correlation)}

Nilai diperoleh dari sejumlah pasangan pixel yang diukur linearitasnya.

$$
\sum_{i=1}^{K} \sum_{j=1}^{K} \frac{\left(i-m_{r}\right)\left(j-m_{c}\right) p_{i j}}{\sigma_{r} \sigma_{c}}
$$

\section{2.1 Klasifikasi}

Klasifikasi dengan metode backpropagation terdiri dari 3 lapisan. Pertama lapisan masukan yang terdiri atas variabel masukan unit, kedua lapisan tersembunyi atau hidden layer, dan ketiga lapisan keluaran. Untuk lapisan masukan terdiri dari 22 variabel yang berasal dari hasil ekstraksi bentuk dan ekstraksi fitur GLCM. Lapisan tersembunyi terdiri atas 5 unit sel saraf, lapisan tersembunyi ditentukan oleh pengguna melalui cara percobaan konvergensi terbaik (trial and error) sampai diperoleh hasil konvergensi pelatihan yang paling baik (jumlah epoch terkecil). Lapisan keluaran terdiri atas 5 class, lapisan keluaran digunakan untuk mempresentasikan pengelompokan pola, yang terdiri dari kelas Bercak, Blas, Hawar Daun, Hawar Pelepah, dan Tungro. Untuk perhitungan klasifikasi ditunjukkan pada persamaan (15)(26)

$$
\begin{gathered}
Z_{-n e t j}=V_{0 j}+\sum_{j=1}^{p} X_{i} V_{i j}(15) \\
Z_{j}=f\left(Z_{-n e t}\right)=\frac{1}{1+e^{-Z_{-} n e t_{-}}}(16) \\
Y_{-n e t k}=w_{0 j}+\sum_{k=1}^{m} Z_{j} W_{j k}(17) \\
y_{k}=f\left(Y_{\text {net } k}\right)=\frac{1}{1+e^{-y_{\text {net }}}}(18) \\
Y_{k}(k=1,2, \ldots, m)(19) \\
\delta_{k}=\left(t_{k}-y_{k}\right) f\left(y_{-n e t ~}\right)=\left(t_{k}-y_{k}\right) y_{k}\left(1-y_{k}\right)(20) \\
\Delta W_{j k}=\alpha \delta_{k} Z_{j}(k=1,2, \ldots, m ; j=0,1,2, \ldots, p)(21) \\
\delta_{-n e t j}=\sum_{k=1}^{m} \delta_{k} W_{j k}(22) \\
\delta_{j}=\delta_{-n e t j} f\left(Z_{-n e t}\right)=\delta_{n e t} Z_{j}\left(1-Z_{j}\right)(23)
\end{gathered}
$$




$$
\begin{gathered}
\Delta V_{i j}=\alpha \delta_{j} X_{j}(j=1,2, \ldots, p ; i=0,1,2, \ldots, n(24) \\
w_{j k}(\text { baru })=w_{j k}(\text { lama })+\Delta w_{j k}(k=1,2, \ldots, m ; j=0,1,2, \ldots, p) \\
v_{i j}(\text { baru })=v_{i j}(\text { lama })+\Delta v_{i j}(j=1,2, \ldots, p ; i=0,1,2, \ldots, n)(26)
\end{gathered}
$$

Testing dan validasi ditunjukkan pada persamaan (27):

$$
\text { Akurasi }=\frac{n_{b}}{N} \times 100 \%
$$

\section{HASIL DAN PEMBAHASAN}

Hasil penelitian yang dilakukan sesuai dengan proses rancangan yang ditunjukkan pada Gambar 5.

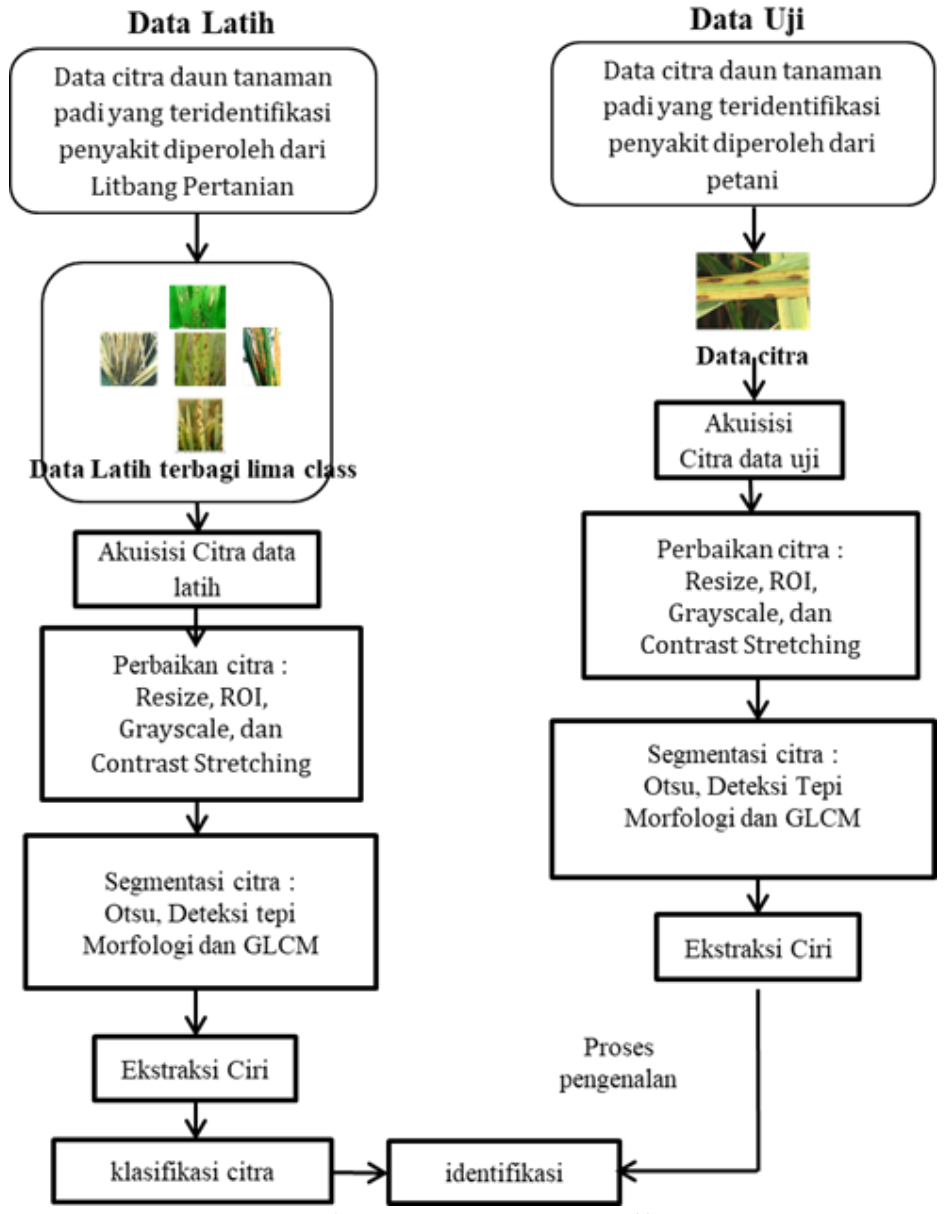

Gambar 5. Proses Pengujian

\subsection{Akuisisi Data}

Hasil akuisisi data citra tanaman padi yang diasumsikan terkena penyakit diproses dan dilakukan ROI (cropping), hasil proses cropping ditunjukkan seperti pada Gambar 6. 


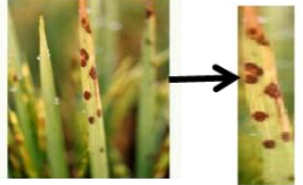

Gambar 6 Citra hasil ROI citra padi bercak_coklat. Hasil image dalam bentuk matrik 293 x 47

\subsection{Perbaikan Citra}

Metode perbaikan citra yang digunakan pada penelitian ini diawali dengan proses grayscale. Proses konversi dari RGB ke grayscale seperti ditunjukkan pada Gambar 7.

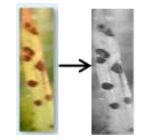

Gambar 7. Hasil Grayscale

Pada peregangan kontras, citra masukan yang greylevelnya tidak penuh dari 0-255 (low contrast) diubah menjadi citra yang grey levelnya berkisar dari $0-255$ (high contrast). Hasil Contrast Stretching ditunjukkan pada Gambar 8.

$\begin{array}{rrrrrrrrr}157 & 196 & 185 & 201 & 219 & 223 & 210 & 180 \\ 187 & 194 & 171 & 166 & 200 & 205 & 191 & 177 \\ 177 & 165 & 159 & 207 & 236 & 202 & 166 & 161 \\ 156 & 157 & 161 & 201 & 173 & 161 & 152 & 140 \\ 133 & 183 & 195 & 181 & 196 & 187 & 190 & 114 \\ 142 & 166 & 169 & 177 & 202 & 212 & 200 & 184 \\ 133 & 154 & 168 & 179 & 172 & 205 & 208 & 221 \\ 62 & 88 & 107 & 147 & 200 & 209 & 204 & 189\end{array}$

Gambar 8. Hasil Contrast Stretching Tabel 1.

Perbandingan hasil perbaikan citra dengan peneliti sebelumnya ditunjukkan 
Tabel 1. Hasil Perbandingan Perbaikan Citra dengan Peneliti Sebelumnya

\begin{tabular}{|c|c|c|c|c|}
\hline \multirow[b]{2}{*}{ No } & \multirow[b]{2}{*}{ Citra ROI } & \multicolumn{3}{|c|}{ PERBANDINGAN HASIL } \\
\hline & & $\begin{array}{c}\text { Contrast } \\
\text { Stretching }\end{array}$ & HSV & Distorsi \\
\hline 1 & Bercak 01 & $=0$ & & \\
\hline 2 & Bercak_02 & $\because 4$ & & \\
\hline 3 & $\underset{\text { Bercak_03 }}{\text { D. }}$ & $\therefore$ & & \\
\hline 4 & Bercak_04 & $\therefore$ & & \\
\hline 5 & Bercak 05 & & & \\
\hline 6 & & & & \\
\hline 7 & Blas_02 & (2) & & \\
\hline 8 & & & & \\
\hline 9 & Blas 04 & 5 & & \\
\hline 10 & Blas 05 & 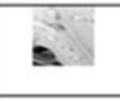 & & \\
\hline
\end{tabular}

\subsection{Segmentasi Citra}

Segmentasi merupakan teknik untuk memisahkan atau membagi antara foreground dan background pada suatu citra. Pada penelitian ini menggunakan teknik thresholding. Thresholding yang digunakan pada penelitian ini adalah otsu thresholding. Pada penelitian yang digunakan oleh [12] menggunakan Fuzzy clustering untuk tahap segmentasi. Hasil segmentasi Fuzzy clustering apabila terdapat objek dengan warna yang sama dengan objek penyakit padi akan tersegmentasi dan hasil segmentasi ternyata bisa berubah-ubah apabila dilakukan pengulangan proses segmentasi dengan data citra yang sama. Metode otsu memilih ambang batas secara otomatis dari tingkat keabu-abuan histogram melalui analisis diskriminan. Analisis diskriminan dapat memaksimalkan pemisahan objek (foreground) dan latar belakang (background). Cara untuk mengubah nilai masing-masing pixel dilakukan berdasarkan nilai threshold pada suatu subimage. Nilai threshold ini diperoleh dengan beberapa tahapan yaitu menghitung normalisasi histogram dari citra, jumlah kumulatif, rata-rata kumulatif, rata-rata intensitas global, varian antar kelas, memilih nilai threshold disebut dengan variabel $\mathrm{k}^{*}$ yang merupakan indeks dimana nilai varian antar kelas maksimum, jika lebih dari satu nilai dari $\mathrm{k}^{*}$, maka nilai threshold ditentukan dari rata-rata nilai $\mathrm{k}^{*}$. Tahap berikutnya menghitung ukuran pemisahan disebut dengan variabel $n^{*}$ dengan $\mathrm{k}=\mathrm{k}^{*}$. Kumpulan pixel warna hitam menunjukkan objek penyakit padi sedangkan kumpulan pixel warna putih menunjukkan latar belakang.

Hasil proses segmentasi Otsu ditunjukkan pada Gambar 9. 


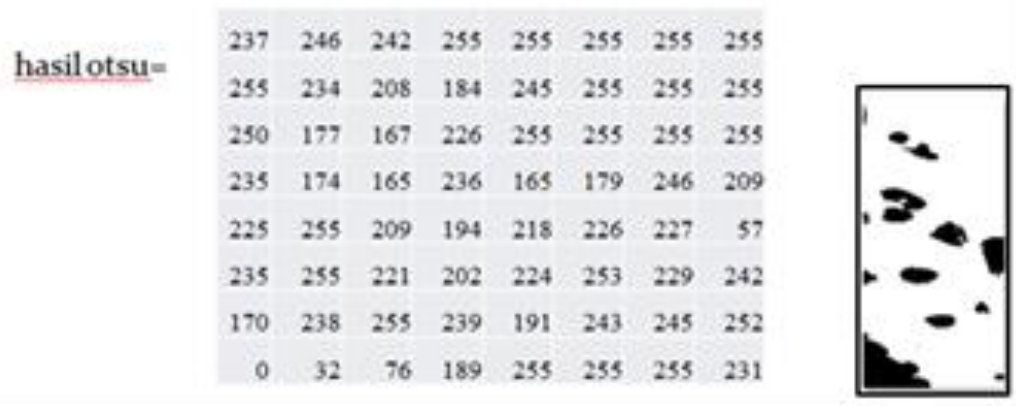

Gambar 9. Hasil Segmentasi Otsu

Hasil segmentasi belum sepenuhnya baik kualitasnya ada bagian-bagian tepian citra yang seharusnya menyambung tetapi tidak tersambung atau bagian-bagian yang seharusnya tidak tersambung justru tersambung. Untuk mengatasi masalah tersebut dilakukan proses morfology [17].

Contoh hasil proses perbandingan proses segmentasi ditunjukkan pada Tabel $\mathbf{2}$

Tabel 2. Hasil Perbandingan Proses Segmentasi

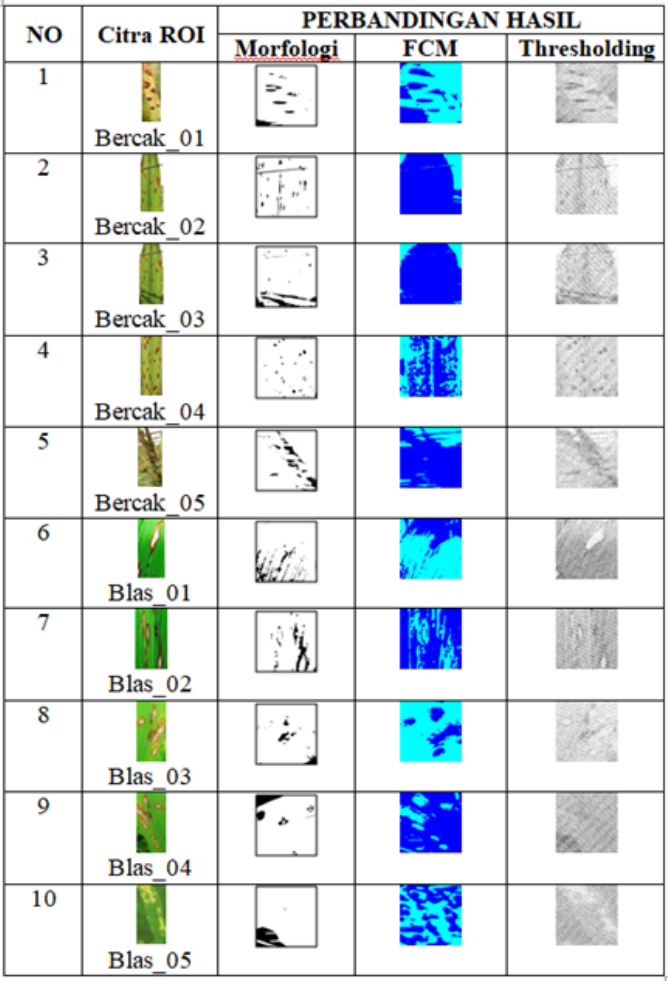

\subsection{Ekstraksi Ciri}

Proses ekstraksi ciri dilakukan setelah tahap segmentasi. Metode ekstraksi ciri yang digunakan adalah ciri bentuk dan ciri tekstur. Parameter ciri bentuk adalah area dan perimeter. ciri berdasarkan tekstur menggunakan pendekatan statistik yaitu ekstraksi ciri statistik orde kedua. ciri statistik orde kedua mempertimbangkan hubungan antara dua pixel (pixel yang bertetangga) pada citra. Analisis tekstur orde dua menggunakan matriks kookurensi (matrix cooccurence) untuk citra keabuan, biasanya disebut GLCM. Orde dua sangat baik 
merepresentasikan tekstur citra pada parameter-parameter terukur, seperti kontras, korelasi, homogenitas, entropi, dan energi. Salah satu metode analisis tekstur yang digunakan adalah Grey Level Co-occurance Matrix (GLCM) dengan jarak spasial 1 dan sudut $0^{\circ}, 45^{\circ}, 90^{\circ}, 135^{\circ}$. Parameter ciri tekstur yang digunakan adalah energi $0^{\circ}$, energi $45^{\circ}$, energi $90^{\circ}$, energi $135^{\circ}$, entropi $0^{\circ}$, entropi $45^{\circ}$, entropi $90^{\circ}$, entropi $135^{\circ}$, kontras $0^{\circ}$, kontras $45^{\circ}$, kontras $90^{\circ}$, kontras $135^{\circ}$, homogeniti $0^{\circ}$, homogeniti $45^{\circ}$, homogeniti $90^{\circ}$, homogeniti $135^{\circ}$, korelasi $0^{\circ}$, korelasi $45^{\circ}$, korelasi $90^{\circ}$, korelasi $135^{\circ}$. Pada tahap ekstraksi ciri, ciri dibagi menjadi 5 kelas. Data citra penyakit padi berjumlah 100 data dibagi menjadi 70 data untuk pelatihan dan 30 data untuk pengujian. Contoh Hasil ekstraksi ciri bentuk dan ciri tekstur disimpan dalam data excel FiturPadi.xml ditunjukkan pada Tabel 3.

Tabel 3. Hasil Ciri Bentuk dan Ciri Tekstur

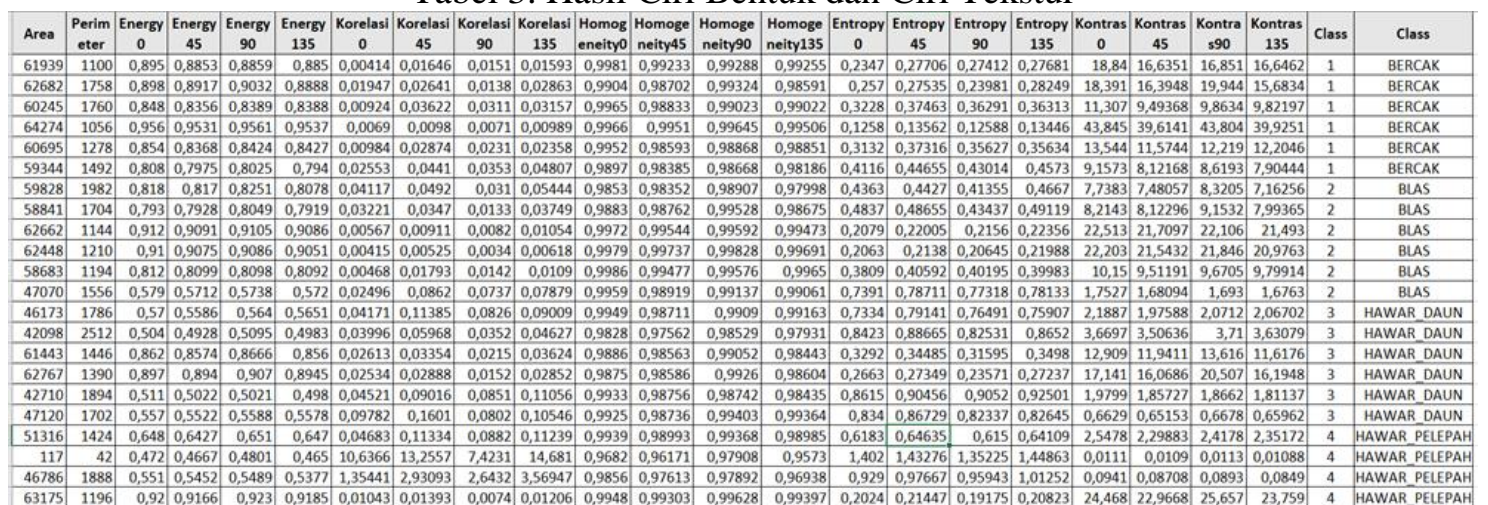

Hasil klasifikasi menggunakan backpropagation ditunjukkan pada Gambar 10,

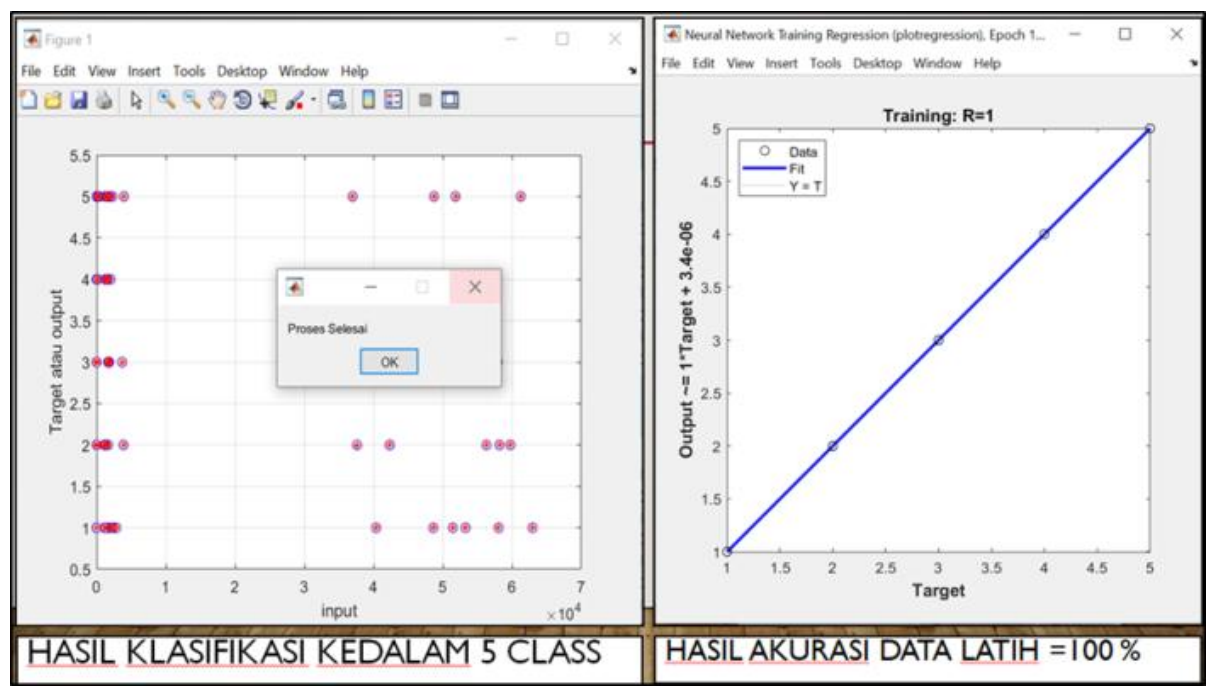

Gambar 10. Hasil Klasifikasi Menggunakan Backpropagation

Hasil pengujian data uji ditunjukkan pada tabel 4, 
Tabel 4. Hasil Data Uji

\begin{tabular}{|c|c|c|c|c|}
\hline No & $\begin{array}{c}\text { DATA } \\
\text { CIIRA UJI }\end{array}$ & $\begin{array}{c}\text { HASIL } \\
\text { PERTANIAN }\end{array}$ & $\begin{array}{l}\text { HASIL UJI } \\
\text { SISTEM }\end{array}$ & AKURASI \\
\hline 1 & & Bercak & Bercak & TRUE \\
\hline 2 & & Bercak & Bercak & TRUE \\
\hline 3 & & Bercak & Bercak & TRUE \\
\hline 4 & & Bercak & Bercak & TRUE \\
\hline 5 & & Blas & Bercaks & FALSE \\
\hline 6 & & Blas & Blas & TRUE \\
\hline$r$ & & Blas & Blas & TRUE \\
\hline 8 & DataUji_ & Blas & Bercak & FALSE \\
\hline 9 & $\mathrm{DataUji}_{\mathrm{i}} 9$ & Hawar_Daun & Hawar_Daun & TRUE \\
\hline 10 & DataUji_ 10 & Hawar_Daun & Hawar_Daun & TRUE \\
\hline
\end{tabular}

Hasil pengujian diperoleh akurasi ditunjukkan pada Gambar 11,

\begin{tabular}{c} 
akurasi $=\frac{\text { (jumlah data }- \text { jumlah salah })}{\text { jumlah data }}$ \\
\hline akurasi $=\frac{(30-2)}{30} * 100 \%$ \\
Akurasi $=93 \%$
\end{tabular}

Gambar 11. Hasil Akurasi dari 30 Data Uji

\section{KESIMPULAN}

Dari hasil pengujian implementasi system identifikasi penyakit pada tanaman padi dengan menggabungkan ciri bentuk dan ciri tekstur diperoleh hasil akurasi dari 70 data latih sebesar $100 \%$, dan hasil pengujian 30 data uji diperoleh hasil 93\%. Sedangkan dari hasil pengujian dengan menggunakan Fuzzy clustering diperoleh hasil 83\%, dan dengan menggunakan distorsi diperoleh hasil $67 \%$.

Dapat disimpulkan dengan penggabungan ciri bentuk dan ciri tekstur dapat meningkatkan hasil akurasi, sehingga dapat digunakan untuk mengidentifikasi penyakit pada tanaman padi dan mempermudah petani dalam menyelesaikan permasalahan tanaman padi yang terserang penyakit.

\section{SARAN}

Untuk saran dalam penelitian berikutnya, supaya meningkatkan hasil yang lebih optimal lagi dapat dilakukan pengujian dengan metode segmentasi yang bervariasi dan juga pengujian 
dengan klasifikasi yang berbeda, sehingga akan dapat diketahui metode klasifikasi yang optimal untuk identifikasi penyakit tanaman padi.

\section{UCAPAN TERIMA KASIH}

Ucapan terima kasih penulis kepada Pemerintah Daerah Wilayah Sragen, Dinas Pertanian wilayah Sragen dan pihak petani yang telah membantu ataupun memberikan dukungan terkait dengan penelitian yang dilakukan. Terima kasih kepada Ibu Dr. Kusrini, M.Kom. yang telah membimbing dalam penelitian, serta kepada pihak-pihak yang telah banyak mendukung dalam penelitian ini.

\section{DAFTAR PUSTAKA}

[1] B. Nuryanto, 2018, "Pengendalian Penyakit Tanaman Padi Berwawasan Lingkungan Melalui Pengelolaan Komponen Epidemik," J. Penelit. dan Pengemb. Pertan., Vol. 37, No. 1, p. 1 .

[2] A. Farid, U. Romadi, and D. Witono, 2018, "Faktor-Faktor yang Mempengaruhi Adopsi Petani dalam Penerapan Sistem Tanam Jajar Legowo di Desa Sukosari Kecamatan Kasembon Kabupaten Malang Provinsi Jawa Timur, ”J. Penyul., Vol. 14, No. 1, pp. 2732.

[3] V. B. Batule, 2016, "Leaf Disease Detection Using Image Processing and Support Vector Machine (SVM)," Vol. 02, No. 02, pp. 74-77.

[4] G. K. P. Vyshnavi, M. R. Sirpa, M. Chandramoorthy, and B. Padmapriya, 2016, "Healthy and Unhealthy Plant Leaf Identification and Classification Using Hierarchical Clustering," pp. 448-453.

[5] C. Senthilkumar and M. Kamarasan, 2018, "A Survey on Leaf Disease Detection Using Image Processing Techniques, "pp. 2-4.

[6] A. A. Bharate and M. S. Shirdhonkar, 2018, "A Review on Plant Disease Detection Using Image Processing,” Proc. Int. Conf. Intell. Sustain. Syst. ICISS 2017, Vol. 20, No. 4, pp. 103-109.

[7] P. P. Warne and S. R. Ganorkar, 2015, "Detection of Diseases on Cotton Leaves Using K-Mean Clustering Method," Int. Res. J. Eng. Technol., Vol. 2, No. 4, pp. 425-431.

[8] M. Shivaji, 2015, "Survey: Detection Of Crop Diseases Using Multiscaling Technique," Int. J. Recent Innov. Trends Comput. Commun, Vol. 3, No. 1, pp. 330-332.

[9] S. I. Chaudhari, M. S. Pathare, S. Haral, Y. Mule, P. Namrata, and K. M. Tech, 2016, " $A$ Survey On Detection Of Unhealthy Region Of Plant Leaves By Using Image Processing," pp. 1318-1320. 
[10] A. K. Dey, M. Sharma, and M. R. Meshram, 2016, "Image Processing Based Leaf Rot Disease, Detection of Betel Vine (Piper BetleL.)," Procedia Comput. Sci., Vol. 85, No. Cms, pp. 748-754.

[11] E. Tuba, R. Jovanovic, and M. Tuba, 2017, "Plant Diseases Detection Based on Color Features and Kapur's Method,” Wseas Trans. Inf. Sci. Appl., Vol. 14, pp. 31-39.

[12] G. Jayanthi, K. S. Archana, and A. Saritha, 2019, "Analysis of Automatic Rice Disease Classification Using Image Processing Techniques," Int. J. Eng. Adv. Technol., Vol. 8, No. 3, pp. 15-20.

[13] G. K. Sandhu and R. Kaur, 2019, “Plant Disease Detection Techniques: A Review, 2019 Int. Conf. Autom. Comput. Technol. Manag. ICACTM 2019, Vol. 8, No. 4, pp. 34-38.

[14] S. Sladojevic, M. Arsenovic, A. Anderla, D. Culibrk, and D. Stefanovic, 2016, "Deep Neural Networks Based Recognition of Plant Diseases by Leaf Image Classification," Comput. Intell. Neurosci.

[15] V. Singh and A. K. Misra, 2017 "Detection of Plant Leaf Diseases Using Image Segmentation and Soft Computing Techniques, ” Inf. Process. Agric.

[16] A. K. Sethy, P. K., Patel, K., Kanta Barpanda, N., \& Rath, 2019, "BRANN Model for Identification of Rice Leaf Diseases Using Texture Feature," No. May, p. 569.

[17] B. R. Gonzalez, R. C., Woods, R. E., \& Masters, 2013. "Digital Image Processing Using Matlab - Gonzalez Woods \& Eddins." 